\title{
Effects of temporary food limitation on development and mortality of Macoma balthica larvae
}

\author{
Oscar G. Bos ${ }^{1,2, *}$, Catharina J. M. Philippart ${ }^{1}$, Jaap van der Meer ${ }^{1}$ \\ ${ }^{1}$ Department of Marine Ecology and Evolution, Royal Netherlands Institute of Sea Research, PO Box 59, \\ 1790 AB Den Burg, The Netherlands \\ ${ }^{2}$ Present address: Wageningen IMARES, Institute for Marine Resources and Ecosystem Studies, PO Box 167, \\ 1790 AD Den Burg, The Netherlands
}

\begin{abstract}
Long-term observations (1973 to 2001) of populations of the intertidal bivalve Macoma balthica, in the western Wadden Sea, have suggested that larval mortality is strongly densitydependent. In addition, density-independent factors may affect larval mortality. One possible source for such an effect is food limitation. In laboratory experiments, $M$. balthica larvae were reared under food limiting conditions, both quantitatively (high or low food level) and temporally (starvation during the first, second or third week). The results indicated that larvae offered high food levels grew significantly faster $\left(6.9 \mu \mathrm{m} \mathrm{d}^{-1}\right)$, and metamorphosed earlier $(16.5 \mathrm{~d})$ and at greater length $(264 \mu \mathrm{m})$ than larvae subjected to low food level $\left(4.4 \mu \mathrm{m} \mathrm{d}^{-1}, 19.3 \mathrm{~d}\right.$ and $244 \mu \mathrm{m}$, respectively). For both food levels, starvation in the first week resulted in a late metamorphosis at a large size, starvation in the second week resulted in an early metamorphosis at a small size, and starvation in the third week yielded intermediate results. Larval mortality was always lower in the low food condition, but the timing of starvation had no impact on mortality. This suggests that larvae, in vivo, do not die directly from food limitation alone. The results are discussed with reference to models of metamorphosis.
\end{abstract}

KEY WORDS: Bivalve larvae $\cdot$ Metamorphosis $\cdot$ Density dependence $\cdot$ Food limitation

\section{INTRODUCTION}

Fecundity of the intertidal bivalve Macoma balthica is proportional to adult stock density (Honkoop \& Van der Meer 1997) (Fig. 1). However, a stock-recruitment relationship is lacking for this species (Van der Meer et al. 2001) (Fig. 1), where recruitment is defined as the number of 0 year-class individuals $(>1 \mathrm{~mm}$ ) present per $\mathrm{m}^{2}$ at the time of sampling in spring, $1 \mathrm{yr}$ after spring spawning. Such an absence of a stock-recruitment relationship has also been demonstrated for other bivalve species (Loosanoff 1966). Thus, there appears to be a limiting factor (carrying capacity) in the larval or juvenile stages that determines maximum recruit density (Van der Meer et al. 2001). The mortality of $M$. balthica larvae or juveniles during the egg-to-recruit phase must thus be strongly density-dependent (Fig. 1) (Van der Meer et al. 2001, Philippart et al. 2003). Small variations in such density-dependent mortality rates may explain the observed year-to-year variation in recruit densities (Van der Meer et al. 2001).

Many mechanisms exist which result in density-dependent mortality of larvae or juveniles, including intra-specific competition (Bertness 1989), diseases (Renault et al. 2000), size selective/aggregative predation (Elmgren et al. 1986, Hiddink et al. 2002) and competition for space (Roughgarden et al. 1985). Another important factor that may determine density-dependent mortality is food availability (Fenaux et al. 1994). A reduction of food levels may be due to competition between larvae, but competition with the adult stock is more probable, which may result in both densitydependent food limitation through a reduction of the food source, and in density-dependent predation of larvae through accidental ingestion. For Macoma balthica larvae, the filtration rates of adult $M$. balthica (Hummel 1985) are probably less important than those of dominant filter feeders such as cockles Cerastoderma edule 


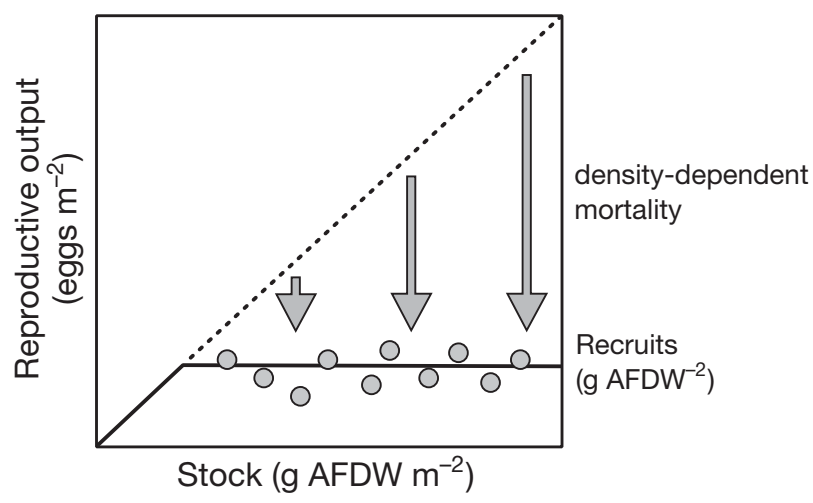

Fig. 1. Macoma balthica. Reproductive output of the bivalve stock. Output is proportional to stock density (Honkoop \& Van der Meer 1997), but a stock-recruitment relationship is lacking (horizontal line) (Van der Meer et al. 2001); hence, the mortality during the egg-to-juvenile (pre-recruit) phase must be strongly density-dependent. AFDW = ash-free dry wt

and mussels Mytilus edulis, which more or less co-vary in abundance with M. balthica (Beukema et al. 2001).

In addition to density-dependent factors, densityindependent factors may contribute to the egg-torecruit mortality, such as match/mismatch of larvae and their food source (Philippart et al. 2003), the water temperature or off-shore transport due to effects of winds (Young et al. 1998). In our study area, the Wadden Sea, the food concentration may vary through time due to wind-driven turbidity and temperature (Cadée 1986).

Food availability will determine both when a larvae metamorphoses and at what size, i.e. excess food will generally result in earlier metamorphosis with a large size being attained with the converse being true when food is scarce (e.g. review in Morey \& Reznick 2000). Differences in food availability may lead to differences in mortality, dispersal ability, age and size at first reproduction, and reproductive output (Smith 1987). For example, in amphibian research metamorphic characters of larval amphibians have attracted great attention because of their high plasticity and their strong influence on fitness (Wilbur \& Collins 1973). Several models of amphibian metamorphosis have been developed to explain size patterns in relation to the timing of metamorphosis (Wilbur \& Collins 1973, Leips \& Travis 1994, Hentschel 1999). In general, metamorphosis models suggest that a minimum size threshold must be attained after which metamorphosis is possible, and that a maximum size exists at which metamorphosis occurs, regardless of environmental conditions (Wilbur \& Collins 1973, Leips \& Travis 1994, Hentschel 1999). The models differ primarily in the degree to which larval development remains flexible with increasing age. Wilbur \& Collins (1973) propose that development remains flexible throughout the larval period, i.e. larvae will initiate metamorphosis when mass-specific growth rates fall below a specific level. In contrast, Leips \& Travis (1994) and Hentschel (1999) propose that development becomes fixed late in the larval period, i.e. after fixation, age at metamorphosis cannot be influenced by environmental circumstances (review in Twombly 1996).

For Macoma balthica, only a few observations have been made on the age and size at which metamorphosis occurs (Drent 2002). No observations have been made in relation to food availability. $M$. balthica larvae probably feed mainly on small unicellular phytoplankton species, as has been demonstrated for the larval Atlantic surfclam Spisula solidissima similis (Walker et al. 1998), in which densities in situ usually vary by several orders of magnitude $\left(10^{2}\right.$ to $10^{5}$ cells $\mathrm{ml}^{-1}$ : Cadée 1986). However, phytoplankton densities used during feeding experiments are usually 5 to $20 \times 10^{4}$ cells $\mathrm{ml}^{-1}$ (e.g. Loosanoff \& Davis 1963), indicating that $M$. balthica larvae in nature may experience sub-optimal food conditions during, at least, part of their development. This may have consequences for the age and size at metamorphosis.

The aims of this study were (1) to examine the in vitro effects of various food levels, both quantitatively and temporally, on mortality in Macoma balthica larvae; (2) to measure the size and age at which M. balthica larvae metamorphose under various food levels, both quantitatively and temporally; (3) to compare the observed results with those predicted by existing metamorphosis models. It was envisaged that low food levels would result in higher larval mortality and slower development compared to high food levels. In addition, early starvation should result in a higher mortality and a slower development rate compared to late starvation, since larvae would not be able to build up energy reserves.

\section{MATERIALS AND METHODS}

General methods. Mature adult Macoma balthica were collected from the Mok Bay, Texel, The Netherlands $\left(53^{\circ} 00^{\prime} \mathrm{N}, 4^{\circ} 45^{\prime} \mathrm{E}\right)$ in March 2001 and stored at $5^{\circ} \mathrm{C}$ in aerated basins $(50 \times 40 \times 10 \mathrm{~cm}), \sim 100$ individuals per basin, prefilled with sandy sediment. The bivalves were fed weekly with a mixture of concentrated algae (Isochrysis sp. and Tetraselmis sp., Reed Mariculture). To provide food for the developing $M$. balthica larvae, fresh I. galbana from a continuous culture system was used.

Production and maintenance of larvae. Macoma balthica were induced to spawn at the beginning of May 2001 following the procedure used by Honkoop et al. (1999). Fertilisation was carried out by pipetting 
eggs of several females into a beaker and adding 1 to $3 \mathrm{ml}$ of sperm suspension derived from 1 or more males. The resultant mixture was left undisturbed overnight at $15^{\circ} \mathrm{C}$. Fertilised eggs (diameter approx. $100 \mu \mathrm{m}$ ) were then separated from all other matter, by rinsing them over stacked sieves of 120 and $50 \mu \mathrm{m}$. Subsequently, they were transferred into 21 conical cylinders containing filtered $(1 \mu \mathrm{m})$ and ultra violet irradiated seawater (UVFS) (salinity: 23 to 25) dosed with $1.5 \times 10^{-5} \mathrm{~g} \mathrm{l}^{-1}$ penicillin $\mathrm{G}$ potassium salt and $2.5 \times 10^{-5} \mathrm{~g} \mathrm{l}^{-1}$ streptomycin sulphate (Drent 2002). The larval cultures were gently stirred by means of air-bubbles and maintained at $15^{\circ} \mathrm{C}$. At Day 3 , the majority of the larvae had reached the D-stage.

Experimental set-up. Three treatments at 2 food levels were applied to the D-larvae (5 replicates per treatment). The food level was high $\left(80 \times 10^{3} \mathrm{cells} \mathrm{ml}^{-1}\right.$ of Isochrysis galbana) or low $\left(4 \times 10^{3}\right.$ cells $\left.\mathrm{ml}^{-1}\right)$. The treatments consisted of a starvation period in the first week, the second week, or the third week (Table 1). The replicates consisted of $80 \mathrm{ml}$ glass-bottles. The initial density of the larvae was $2 \mathrm{ml}^{-1}$. To mix the water, all treatments were placed on a rollertable (4 to $5 \mathrm{rpm}$ ) and the water (UVFS) was changed 3 times per week.

Mortality. Larval densities were measured for each replicate (3 sub-samples per replicate) at Days 8, 15 and 22. The density at Day 8 was considered as the initial density. After the analysis, larvae were rinsed back into the bottles. The mortality rate was obtained from fitting a regression line through the natural logarithms of the densities through time, according to:

$$
\ln \left(N_{t}\right)=\ln \left(N_{0}\right)+r t,
$$

where $N_{t}$ is the density of larvae at time $t$ (larvae $\mathrm{ml}^{-1}$ ), $N_{0}$ is the initial density at Day 8 (larvae $\mathrm{ml}^{-1}$ ), $r$ is the mortality rate $\left(\mathrm{d}^{-1}\right)$ and $t$ is age $(\mathrm{d})$ of the larvae.

Table 1. Macoma balthica. Overview of experimental set-up of 2-factor larval growth experiment over $3 \mathrm{wk}$ period, whereby starvation period was introduced in first, second or third week. High $(\mathrm{H})=80000$ cells Isochrysis galbana $\mathrm{ml}^{-1}$, Low $(\mathrm{L})=4000$ cells $\mathrm{ml}^{-1}, 0=0$ cells ml $\mathrm{m}^{-1}$ (starvation). (e.g. $0 \mathrm{HH}=$ starvation in Week 1 with high food levels in Weeks 2 and $3, \mathrm{HOH}=$ high food levels in Weeks 1 and 3 and starvation in Week 2)

\begin{tabular}{|lcc|}
\hline Food level & Starvation week & Code \\
\hline High & 1 & OHH \\
& 2 & HOH \\
& 3 & HHO \\
Low & 1 & OLL \\
& 2 & LOL \\
& 3 & LL0 \\
\hline
\end{tabular}

Growth. The shell length of 15 to 25 individuals per replicate was measured at Days 5, 10, 15, 17, 20 and 24 to the nearest $0.10 \mu \mathrm{m}$. The initial shell length at Day 3 (D-larvae) was $160 \pm 1.5 \mu \mathrm{m}$ for all treatments. Growth rate $\left(\mu \mathrm{m} \mathrm{d}^{-1}\right)$ was calculated with the linear model:

$$
\mathrm{SL}=160+b(\text { Age }-3)
$$

where SL = shell length $(\mu \mathrm{m}), 160$ is the initial shell length $(\mu \mathrm{m})$ at Day 3 , and $b$ is the growth rate $\left(\mu \mathrm{m} \mathrm{d}^{-1}\right)$.

Development. The absence or presence of a foot was scored to determine larval development status. Larvae that showed a clearly visible foot bulging out of the shell (pediveligers) were considered to have metamorphosed. Average values for age at metamorphosis were calculated for each treatment with the logistic regression:

$$
\ln \left[\mathrm{p}(1-\mathrm{p})^{-1}\right]=\alpha+b \text { Age }
$$

where $\mathrm{p}$ is the probability of passing metamorphosis. Average values for shell length at metamorphosis were calculated with the logistic regression:

$$
\ln \left[\mathrm{p}(1-\mathrm{p})^{-1}\right]=\alpha+b \mathrm{SL}
$$

To take into account the effects of food level, staration period or any interactions, various logistic regression models were fitted to the data on absence or presence of a foot. The models were of the form:

$$
\ln \left[\mathrm{p}(1-\mathrm{p})^{-1}\right]=1 p,
$$

where $1 p$ is the linear predictor, calculated as the sum of a constant $\alpha$ and the effects of independent factors and interactions of these factors. The model with the lowest sum of the deviance and $\zeta$ times the number of estimable parameters should be used, where $\zeta$ is a penalty for adding extra parameters to the model. By convention, $\zeta$ ranges between 2 and 6 (Atkinson 1981). The age and size at which $50 \%$ of the larvae had metamorphosed (reaction norm) were calculated by setting $\mathrm{p}$ at 0.5 in the best fitting logistic regression model, yielding $l p=\ln [0.5 /(1-0.5)]$, i.e. $1 p=0$.

\section{RESULTS}

\section{Mortality}

The initial density (i.e. at Day 8) was $0.88 \pm 0.03$ larvae $\mathrm{ml}^{-1}$ (mean $\pm \mathrm{SE}$ ). At the high food levels, the larval density was reduced by $69 \%$ to $0.28 \pm 0.01$ larvae $\mathrm{ml}^{-1}$ at Day 22 (Fig. 2). In contrast, at the low food levels, the density was reduced by $58 \%$ to $0.37 \pm 0.04$ larvae $\mathrm{ml}^{-1}$ (Fig. 2). Analysis of the mortality rates, using analysis of variance (ANOVA), revealed that at the high food levels $\left(0.036 \pm 0.001 \mathrm{~d}^{-1}\right.$, mean $\pm \mathrm{SE})$, mortality rates were higher than at the 

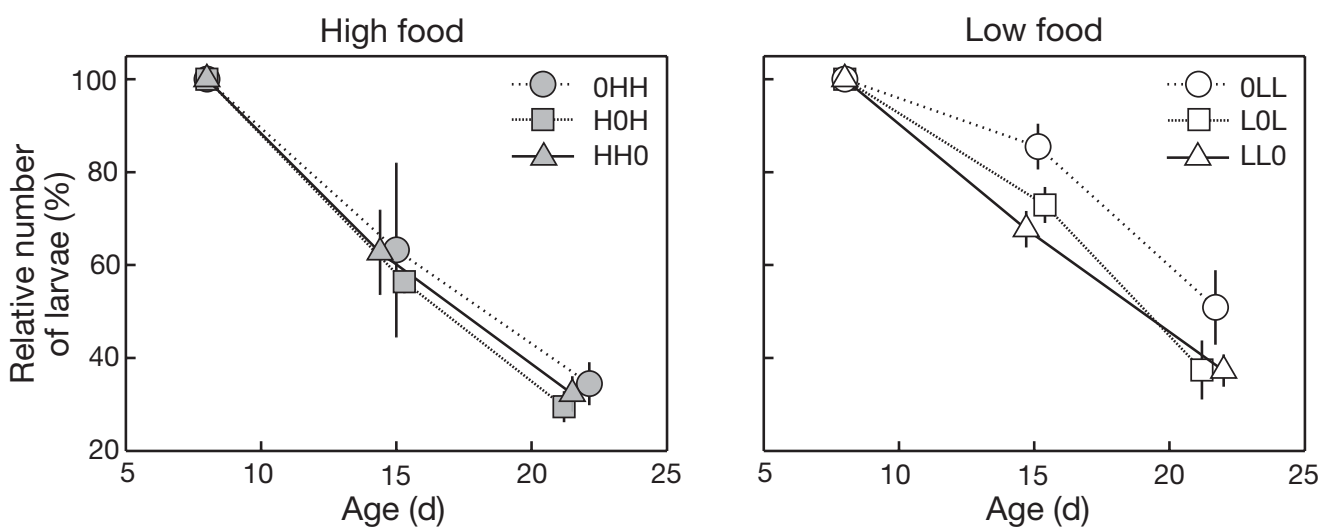

Fig. 2. Macoma balthica. Relative number of larvae (mean \pm SE from Days 8 to 22 at high and low food levels). For clarity, data are slightly offset along $x$-axis. See Table 1 for treatment codes

low food levels $\left(0.023 \pm 0.003 \mathrm{~d}^{-1}\right)$ (Tables $\left.2 \& 3\right)$. The timing of the starvation period (first, second or third week) had no effect on larval mortality rates (Table 3).

\section{Growth}

The initial shell length at Day 3 was $160 \pm 1.5 \mu \mathrm{m}$ (mean \pm SE) for all treatments. At Day 24, larvae in the low (L) food level treatments had a shell length between $228 \pm 18 \mu \mathrm{m}$ (OLL) and $266 \pm 8 \mu \mathrm{m}$ (LL0), while larvae in the high $(\mathrm{H})$ food levels had a shell length between $292 \pm 19 \mu \mathrm{m}(\mathrm{OHH})$ and $319 \pm 15 \mu \mathrm{m}(\mathrm{HOH})$ (Fig. 3, Table 2).

On average, larvae grew at a rate of $5.7 \pm 0.7 \mu \mathrm{m} \mathrm{d}^{-1}$ (mean $\pm \mathrm{SE})$ (Table 2). Analysis using ANOVA revealed that larvae at the high food levels grew faster $\left(6.9 \pm 0.6 \mu \mathrm{m} \mathrm{d}^{-1}\right)$ than larvae reared at the low food levels $\left(4.4 \pm 0.5 \mu \mathrm{m} \mathrm{d}^{-1}\right)$ (Table 3$)$. Pairwise comparisons using Bonferroni's method revealed a signifi- cantly lower growth rate of larvae starved in the first week $\left(4.4 \pm 0.8 \mu \mathrm{m} \mathrm{d}^{-1}\right)$ compared to growth rate of larvae starved in the second $\left(6.2 \pm 0.5 \mu \mathrm{m} \mathrm{d}^{-1}\right)$ and third week $\left(6.4 \pm 0.6 \mu \mathrm{m} \mathrm{d}^{-1}\right)$ (Fig. 3, Table 3). Correlation of larval growth rates and larval mortality rates revealed a positive correlation $\left(\mathrm{r}^{2}=0.76, \mathrm{p}=0.01\right)$ (Fig. 4).

\section{Development}

The average age at metamorphosis was $17.9 \pm 1.1 \mathrm{~d}$ (mean $\pm \mathrm{SE}$ ) at a length of $254 \pm 6 \mu \mathrm{m}$ (mean $\pm \mathrm{SE}$ ) (Table 2). For the high food levels, metamorphosis occurred at an earlier age $(16.5 \pm 1.5 \mathrm{~d})$, and at greater length $(264 \pm 6 \mu \mathrm{m})$, than for the low food levels $(19.3 \pm$ $1.2 \mathrm{~d}$ and $244 \pm 6 \mu \mathrm{m}$, respectively) (Fig. 5, Table 2). Furthermore, larvae starved in the second week metamorphosed earlier and at smaller length than larvae starved in the first or third week (Fig. 5). Larvae starved in the third week metamorphosed latest and at greatest lengths (Fig. 5).

Table 2. Macoma balthica. Larval mortality rates between Days 8 and 24, shell length (SL) at Day 24, growth rates between Days 3 and 24, age at metamorphosis and shell length at metamorphosis. Data are means \pm SE. Treatment codes in Table 1

\begin{tabular}{|lccccc|}
\hline Code & Mortality $\left(\mathrm{d}^{-1}\right)$ & $\begin{array}{c}\text { SL at Day } 24 \\
(\mu \mathrm{m})\end{array}$ & $\begin{array}{c}\text { Growth } \\
\left(\mu \mathrm{m} \mathrm{d}^{-1}\right)\end{array}$ & $\begin{array}{c}\text { Age at } \\
\text { metamorphosis } \\
(\mathrm{d})\end{array}$ & $\begin{array}{c}\text { SL at } \\
\text { metamorphosis } \\
(\mu \mathrm{m})\end{array}$ \\
\hline OHH & $0.035 \pm 0.003$ & $291.9 \pm 19.3$ & $5.51 \pm 1.09$ & $19.4 \pm 1.3$ & $274.8 \pm 3.1$ \\
HOH & $0.038 \pm 0.003$ & $319.2 \pm 15.3$ & $7.61 \pm 0.45$ & $14.3 \pm 0.2$ & $252.5 \pm 0.5$ \\
HH0 & $0.035 \pm 0.007$ & $312.2 \pm 19.7$ & $7.69 \pm 0.78$ & $15.8 \pm 0.3$ & $264.6 \pm 8.2$ \\
OLL & $0.021 \pm 0.005$ & $227.5 \pm 17.7$ & $3.28 \pm 0.87$ & $21.7 \pm 0.8$ & $255.2 \pm 3.3$ \\
LOL & $0.030 \pm 0.006$ & $258.2 \pm 5.1$ & $4.87 \pm 0.17$ & $17.6 \pm 0.7$ & $234.1 \pm 2.7$ \\
LL0 & $0.030 \pm 0.003$ & $265.5 \pm 7.7$ & $5.17 \pm 0.37$ & $18.5 \pm 0.9$ & $244.0 \pm 2.5$ \\
High & $0.036 \pm 0.001$ & $307.8 \pm 8.2$ & $6.94 \pm 0.63$ & $16.5 \pm 1.5$ & $264.0 \pm 6.4$ \\
Low & $0.027 \pm 0.003$ & $250.4 \pm 11.6$ & $4.44 \pm 0.45$ & $19.3 \pm 1.2$ & $244.4 \pm 6.1$ \\
Overall mean & $0.031 \pm 0.003$ & $279.1 \pm 14.3$ & $5.69 \pm 0.69$ & $17.9 \pm 1.1$ & $254.2 \pm 5.9$ \\
\hline
\end{tabular}


Table 3. ANOVA of the effects of Food level and Starvation week on the mortality rate and growth rate of Macoma balthica larvae. $\mathrm{SS}=$ sum of squares, $\mathrm{df}=$ degrees of freedom, $\mathrm{MS}=$ mean squares, Week $1=$ starvation period during Week 1 , Week 2 = starvation period during Week 2 , Week $3=$ starvation period during Week 3. ns $=$ not significant; ${ }^{*} p \leq 0.05 ;{ }^{* *} p \leq 0.01$; ${ }^{* * *} \mathrm{p} \leq 0.001$

\begin{tabular}{|c|c|c|c|c|c|c|c|c|}
\hline \multirow[t]{2}{*}{ Source } & \multicolumn{4}{|c|}{ - Mortality rate $\left(\mathrm{d}^{-1}\right)$} & \multicolumn{4}{|c|}{ Growth rate $\left(\mu \mathrm{m} \mathrm{d}^{-1}\right)$} \\
\hline & $\begin{array}{c}\text { SS } \\
\left(\times 10^{-3}\right)\end{array}$ & $\underset{\left(\times 10^{-3}\right)}{\mathrm{df}}$ & MS & $F$ & SS & df & MS & $F$ \\
\hline Food level & 5.853 & 1 & 5.853 & $5.51^{*}$ & 46.89 & 1 & 46.89 & $19.24^{* * *}$ \\
\hline Starvation week & 1.893 & 2 & 0.946 & $0.89^{\mathrm{ns}}$ & 25.19 & 2 & 12.59 & $5.17^{* * *}$ \\
\hline Starvation week $\times$ Food level & 0.962 & 2 & 0.481 & $0.45^{\mathrm{ns}}$ & 0.33 & 2 & 0.17 & $0.07^{\mathrm{ns}}$ \\
\hline Error & 23.369 & 22 & 1.062 & & 58.48 & 24 & 2.44 & \\
\hline $\begin{array}{l}\text { Pairwise comparisons } \\
\text { of starvation week }\end{array}$ & \multicolumn{4}{|c|}{$($ Week $1=$ Week $2=$ Week 3$)$} & \multicolumn{4}{|c|}{ Week $1<($ Week 2 = Week 3$)$} \\
\hline
\end{tabular}

Analysis of the data revealed that the model with the lowest sum of the deviance and $\zeta$ times the number of estimable parameters was $l p=\alpha+$ (week $\times$ age $)+($ week $\times$ length) $($ Table 4$)$. According to this model the probability of passing metamorphosis is a function of shell length and age. Furthermore, the

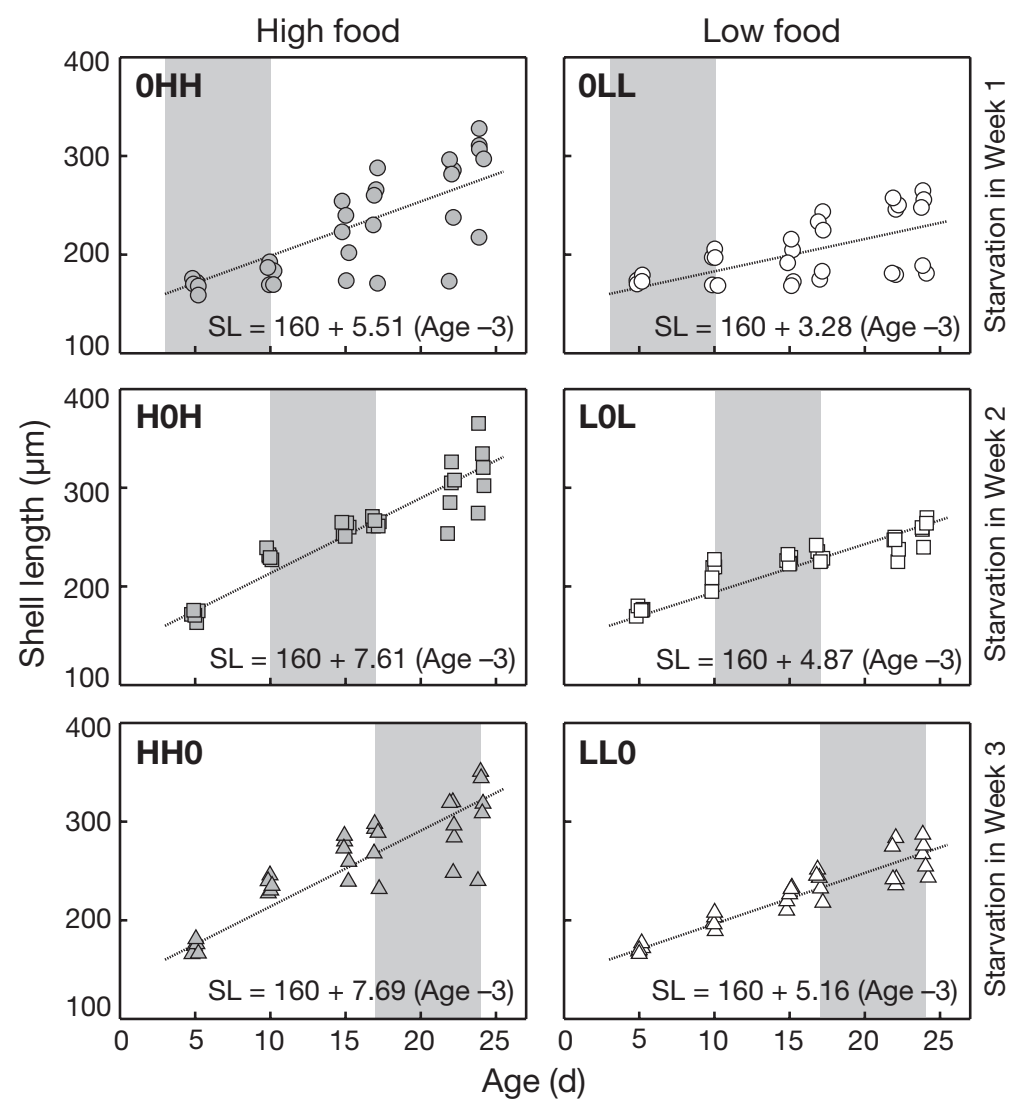

Fig. 3. Macoma balthica. Larval shell length per replicate for each treatment. Shaded blocks indicate weeks without food. Regression lines show growth rates $\left(\mu \mathrm{m} \mathrm{d}^{-1}\right)$ and are forced through the initial shell length of $160 \mu \mathrm{m}$ at Day 3. For clarity, data are slightly offset along $x$-axis. See Table 1 for treatment codes value of the function $(l p)$ differs per starvation period (Fig. 6).

A posteriori models used for pairwise comparisons of starvation weeks showed that starvation in Week 1 versus starvation in Weeks 2 and 3 resulted in a lower sum of the deviance and $\zeta$ times the number of estimable parameters than any other combination of starvation weeks (Table 4). This implies that an early starvation period leads to metamorphosis at a significantly larger size and higher age.

\section{DISCUSSION}

The current experiment revealed that at high food levels, Macoma balthica larvae grew faster (6.9 $\left.\mathrm{mm} \mathrm{d}^{-1}\right)$ and metamorphosed earlier $(16.5 \mathrm{~d})$ at greater size $(264 \mu \mathrm{m})$, than at low food levels $\left(4.4 \mu \mathrm{m} \mathrm{d}^{-1}, 19.3 \mathrm{~d}\right.$ and $244 \mu \mathrm{m}$, respectively). In addition, it was determined that the probability of passing metamorphosis is a function of both age and size, where the value of the function is determined by the timing of the starvation period. Similar observations have been made for a variety of taxa, such as insects, amphibians and crustaceans (reviews in Twombly 1996, Morey \& Reznick 2000). In particular, most species show a reduced age at metamorphosis (or maturity) with increasing growth conditions, often accompanied by a larger size at the transition.

The average growth rate recorded $\left(5.7 \mu \mathrm{m} \mathrm{d}^{-1}\right)$ compares well to that found by Drent (2002) of $5.2 \mu \mathrm{m} \mathrm{d}^{-1}$ for Macoma balthica larvae at $15^{\circ} \mathrm{C}$, as do the average age and size at metamorphosis, i.e. $20.6 \mathrm{~d}$ 


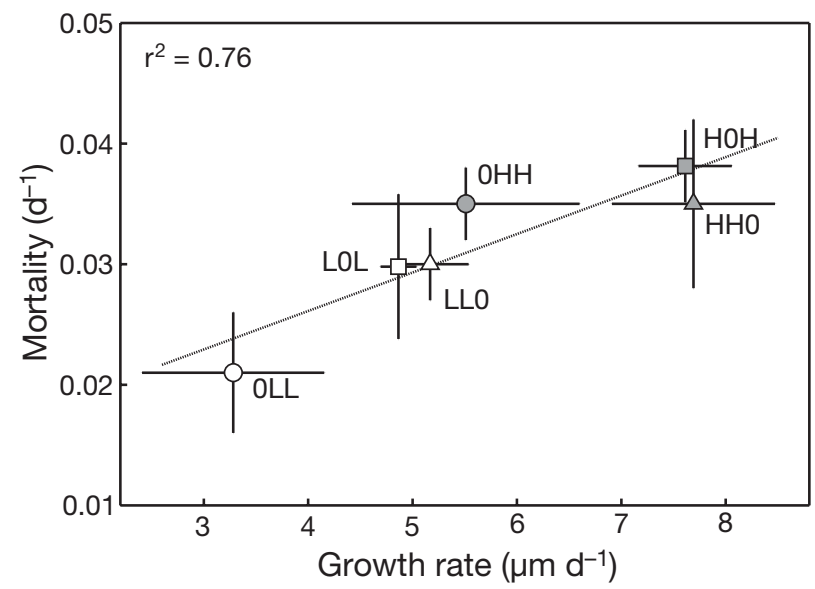

Fig. 4. Macoma balthica. Larval mortality (mean \pm SE) plotted against growth rate. See Table 1 for treatment codes

and $254 \mu \mathrm{m}$ (Drent 2002). In contrast, the recorded mortality rates $\left(0.02\right.$ to $\left.0.04 \mathrm{~d}^{-1}\right)$ in the experiments were slightly lower than the egg-to-recruit mortality rate of $0.05 \mathrm{~d}^{-1}$ determined by Philippart et al. (2003) and much lower than the range of natural daily mortality rates of meroplanktonic larvae of 0.13 to $0.28 \mathrm{~d}^{-1}$ (review in Rumrill 1990). However, such results arise from the absence of predators, diseases, etc. in in vitro conditions.

Although it was predicted that the effect of timing of starvation on mortality would be greatest when the larvae started feeding, i.e. directly after the lecitho-

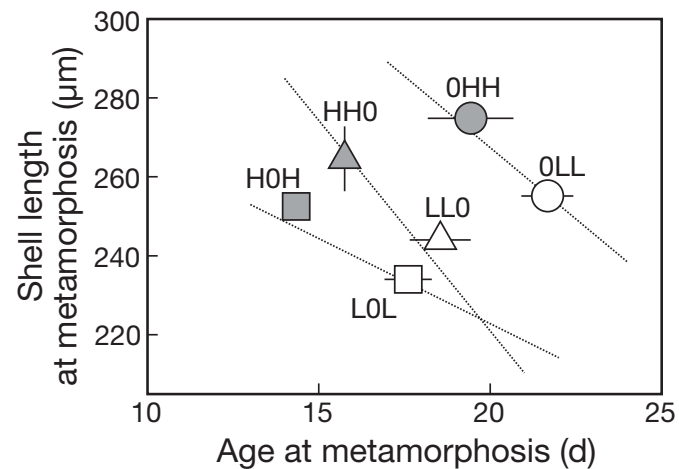

Fig. 5. Macoma balthica. Larval age and shell length (mean \pm SE) at metamorphosis for different treatments, calculated with simple logistic models (see 'Materials and methods'). For comparison, regression lines of Fig. 6 are included. See Table 1 for treatment codes

trophic phase, mortality rates in early starvation periods were no different from mortality rates in later periods (Table 4). The length of the starvation period $(7 \mathrm{~d})$ was clearly not long enough to directly affect larval mortality. Larvae may have used energy reserves in the form of lipids to survive these periods. These reserves could have been built up in the period when larvae were provided with food or, for larvae that did not receive food in the first week, remained from the eggs (Videla et al. 1998). For instance, unfed surfclam larvae (Spisula solidissima solidissima) survived up to $15 \mathrm{~d}$ (Walker et al. 1998).

Table 4. Goodness-of-fit (in terms of deviance, Dev.) of the various models and the sum of the deviance and $\zeta$ times the number of estimable parameters (No. est) for $\zeta=2,4$ and 6 (see 'Materials and methods'). Model with the lowest sum $\left({ }^{*}\right.$ ) is preferred. Age = age of Macoma balthica larvae (d), Length = shell length of larvae $(\mu \mathrm{m})$, Week = starvation week (Week 1, Week 2 and Week 3), Food $=$ food level (high and low), Treatment $=$ combination of Week and Food

\begin{tabular}{|c|c|c|c|c|c|c|c|}
\hline $\begin{array}{l}\text { Mod } \\
\text { No. }\end{array}$ & Model & df & Dev. & No. est & $(\zeta=2)$ & $\begin{array}{l}\text { Deviance } \\
(\zeta=4)\end{array}$ & $(\zeta=6)$ \\
\hline 1 & Constant & 2580 & 3219 & 1 & 3221 & 3223 & 3225 \\
\hline 2 & Age & 2579 & 1993 & 2 & 1997 & 2001 & 2005 \\
\hline 3 & Length & 2579 & 1528 & 2 & 1532 & 1536 & 1540 \\
\hline 4 & Age + Length & 2578 & 1210 & 3 & 1216 & 1222 & 1228 \\
\hline 5 & Food $\times$ Age & 2577 & 1880 & 4 & 1888 & 1896 & 1904 \\
\hline 6 & Food $\times$ Length & 2577 & 1457 & 4 & 1465 & 1473 & 1481 \\
\hline 7 & Week + Age + Length & 2576 & 1025 & 5 & 1035 & 1045 & 1055 \\
\hline 8 & Week $\times$ Age & 2575 & 1653 & 6 & 1665 & 1677 & 1689 \\
\hline 9 & Week $\times$ Length & 2575 & 1425 & 6 & 1437 & 1449 & 1461 \\
\hline 10 & $($ Food $\times$ Age $)+($ Food $\times$ Length $)$ & 2575 & 1199 & 6 & 1211 & 1223 & 1235 \\
\hline 11 & $($ Week $\times$ Age $)+($ Week $\times$ Length $)$ & 2572 & 994 & 9 & 1012 & $1030^{*}$ & $1048^{*}$ \\
\hline 12 & $($ Food $\times$ Age $)+($ Food $\times$ Length $)+$ & & 087 & & 1011 & & 1050 \\
\hline 13 & (Treatment $\times$ Age $)+($ Treatment $\times$ Length) & $\begin{array}{l}2569 \\
2491\end{array}$ & $\begin{array}{l}98 t \\
801\end{array}$ & $\begin{array}{l}12 \\
90\end{array}$ & $981^{*}$ & $\begin{array}{l}1035 \\
1161\end{array}$ & $\begin{array}{l}1059 \\
1341\end{array}$ \\
\hline \multicolumn{8}{|c|}{$\begin{array}{l}\text { Post-hoc cross comparisons between treatments effects (i.e. timing of starvation) using Model } 11 \text { as the base, which is } \\
\text { considered as the best model (lowest sum at ' } 4 \text { ' and ' } 6 \text { ' levels) }\end{array}$} \\
\hline \multicolumn{3}{|c|}{$\begin{array}{l}\text { Week } 1<(\text { Week } 2=\text { Week } 3) \\
(p<0.05)\end{array}$} & & & & & \\
\hline
\end{tabular}


In the current experiment the minimum size at which metamorphosis occurred was approximately $200 \mu \mathrm{m}$ (Fig. 6) and the relation between age and size at metamorphosis (reaction norm) was negative, i.e. fast growing larvae metamorphosed earlier at larger size than slow growing larvae. These results support both fixed and flexible development models. Furthermore, starvation in the second week led to an earlier metamorphosis at smaller size than starvation in the third week (Fig. 5). These results support the flexible development model of Wilbur \& Collins (1973), in which at rapid growth rates metamorphosis is delayed to capitalise on this growth and at slow growth rates metamorphosis is initiated to leave the deteriorating habitat (Wilbur \& Collins 1973).

The results demonstrated that larvae metamorphosed successfully in all treatments and that larvae adjusted their age and size at metamorphosis to different food limiting conditions, while mortality rates were not increased at the low food levels or in early starvation periods. The ecological meaning of the results is not clear yet, since the diet of the Macoma balthica larvae consisted of Isochrysis galbana and not of a natural phytoplankton assemblage. In another experiment (Bos et al. 2006) in which $M$. balthica larvae were reared on natural phytoplankton, however, larvae often did not metamorphose due to food limitation, suggesting that some minimal energy intake is required to complete metamorphosis. The mortality rate also did not increase with decreasing food levels, as observed in this experiment. $M$. balthica larvae in nature are therefore supposedly adapted to varying food supplies to a certain extent, by possessing sufficient energy reserves to survive temporary or longterm food limitation, as has been reported for Crassostrea virginica larvae (Loosanoff 1974).

The results suggest that direct mortality through food limitation is not likely as a mechanism causing strong density-dependent or density-independent larval mortality. The observed egg-to-recruit density-dependent mortality of Macoma balthica in the Western Wadden Sea (Van der Meer et al. 2001) may, however, be the result of a combination of factors. Assuming that larvae and adults compete for the same food source, and that larvae are accidentally ingested by the adult stock (André \& Rosenberg 1991), then larvae will be
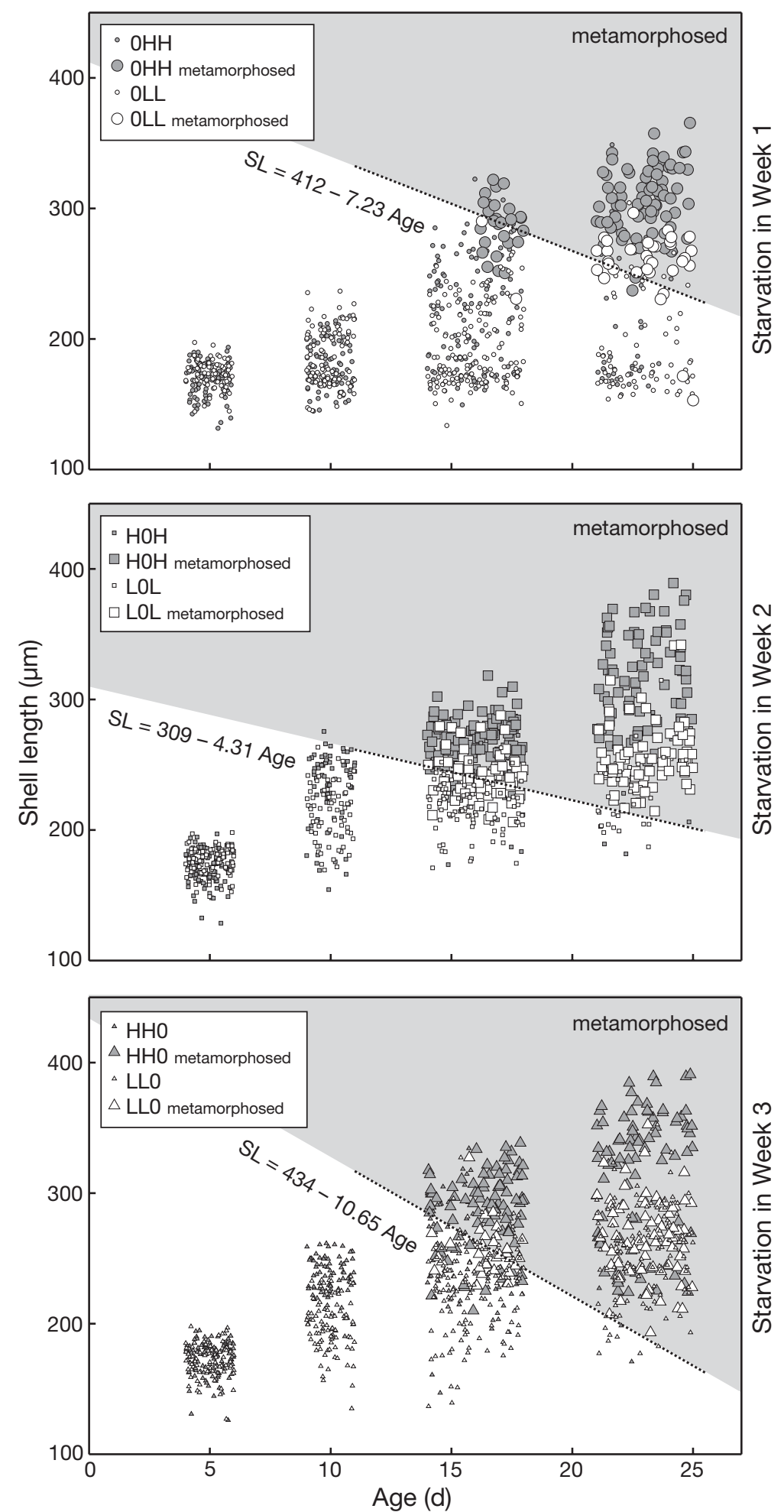

Fig. 6. Macoma balthica. Age (d) and shell length (SL) of individual larvae starved in the first, second or third week. Small symbols indicate non-metamorphosed larvae, large symbols metamorphosed individuals. Regressions indicate the transition to metamorphosis (reaction norms) and are calculated from the best fitting logistic model (see Table 4). For clarity, data are offset along $x$-axis. See Table 1 for treatment codes 
more food limited at higher adult stock densities, resulting in a longer pelagic period, with an increased risk of being predated (Philippart et al. 2003). Food limitation also results in a smaller size at settlement, which make the juveniles more likely to be predated upon by size-selective shrimp (e.g. Hiddink et al. 2002). Such shrimp predation may be density-dependent, characterised by some density level below which predation is no longer profitable. Finally, food limitation in the larval phase may be followed by a poor juvenile condition in the post-settlement phase, resulting in increased post-settlement mortality (Phillips 2002).

Acknowledgements. We are grateful to J. Hegeman for supporting the maintenance of the algal cultures. W.J. Wolff, S.P. Holmes and 4 anonymous referees made valuable comments on earlier drafts. We acknowledge T. Day for fruitful discussions. Funding for this study was provided by the Netherlands Organisation for Scientific Research (Priority Programme on Sustainable Use and Conservation of Marine Living Resources).

\section{LITERATURE CITED}

André C, Rosenberg R (1991) Adult-larval interactions in the suspension-feeding bivalves Cerastoderma edule and Mya arenaria. Mar Ecol Prog Ser 71:227-234

Atkinson AC (1981) A comparison of 2 criteria for the design of experiments for discriminating models. Technometrics 23:301-305

Bertness MD (1989) Intraspecific competition and facilitation in a northern acorn barnacle population. Ecology 70: $257-268$

Beukema JJ, Dekker R, Essink K, Michaelis H (2001) Synchronized reproductive success of the main bivalve species in the Wadden Sea: causes and consequences. Mar Ecol Prog Ser 211:143-155

Bos OG, Philippart CJM, Cadée GC, van der Meer J (2006) Recruitment variation in Macoma balthica: a laboratory examination of the match/mismatch hypothesis. Mar Ecol Prog Ser 320:207-214

Cadée GC (1986) Recurrent and changing seasonal patterns in phytoplankton of the westernmost inlet of the Dutch Wadden Sea from 1969 to 1985. Mar Biol 93:281-289

Drent J (2002) Temperature responses in larvae of Macoma balthica from a northerly and southerly population of the European distribution range. J Exp Mar Biol Ecol 275: $117-129$

Elmgren R, Ankar S, Marteleur B, Ejdung G (1986) Adult interference with postlarvae in soft sediments: the Pontoporeia-Macoma example. Ecology 67:827-836

Fenaux L, Strathmann MF, Strathmann RR (1994) Five tests of food-limited growth of larvae in coastal waters by comparisons of rates of development and form of echinoplutei. Limnol Oceanogr 39:84-98

Hentschel BT (1999) Complex life cycles in a variable environment: predicting when timing of metamorphosis shifts from resource dependent to developmentally fixed. Am Nat 154:549-558

Hiddink JG, Marijnissen SAE, Troost K, Wolff WJ (2002) Predation on 0-group and older year classes of the bivalve Macoma balthica: interaction of size selection and inter-

Editorial responsibility: Otto Kinne (Editor-in-Chief),

Oldendorf/Luhe, Germany tidal distribution of epibenthic predators. J Exp Mar Biol Ecol 269:223-248

Honkoop PJC, van der Meer J (1997) Reproductive output of Macoma balthica populations in relation to wintertemperature and intertidal-height mediated changes of body mass. Mar Ecol Prog Ser 149:155-162

Honkoop PJC, Luttikhuizen PC, Piersma T (1999) Experimentally extending the spawning season of a marine bivalve using temperature change and fluoxetine as synergistic triggers. Mar Ecol Prog Ser 180:297-300

Hummel H (1985) Food intake of Macoma balthica (Mollusca) in relation to seasonal changes in its potential food on a tidal flat in the Dutch Wadden Sea. Neth J Sea Res 19: $52-76$

Leips J, Travis J (1994) Metamorphic responses to changing food levels in two species of hylid frogs. Ecology 75 : $1345-1356$

Loosanoff VL (1966) Time and intensity of setting of the oyster, Crassostrea virginica, in Long Island Sound. Biol Bull (Woods Hole) 130:211-227

Loosanoff VL (1974) Factors responsible for the mass mortalities of molluscan larvae in nature: a review. Proc World Maricult Soc 5:297-309

Loosanoff VL, Davis HC (1963) Rearing of bivalve molluscs. Adv Mar Biol 1:1-136

Morey S, Reznick D (2000) A comparative analysis of plasticity in larval development in three species of spadefoot toads (Anura: Pelobatidae: Scaphiopus). Ecology 81: $1736-1749$

Philippart CJM, Van Aken HM, Beukema JJ, Bos OG, Cadée GC, Dekker R (2003) Climate-related changes in recruitment of the bivalve Macoma balthica. Limnol Oceanogr 48:2171-2185

Phillips NE (2002) Effects of nutrition-mediated larval condition on juvenile performance in a marine mussel. Ecology 83:2562-2574

Renault T, Le Deuff RM, Chollet B, Cochennec N, Gérard A (2000) Concomitant herpes-like virus infections in hatchery-reared larvae and nursery-cultured spat Crassostrea gigas and Ostrea edulis. Dis Aquat Org 42:173-183

Roughgarden J, Iwasa Y, Baxter C (1985) Demographic theory for an open marine population with space-limited recruitment. Ecology 66:54-67

Rumrill SS (1990) Natural mortality of marine invertebrate larvae. Ophelia 32:163-198

Smith DC (1987) Adult recruitment in chorus frogs: effects of size and date at metamorphosis. Ecology 68:344-350

Twombly S (1996) Timing of metamorphosis in a freshwater crustacean: comparison with anuran models. Ecology 70 : 1855-1866

van der Meer J, Beukema JJ, Dekker R (2001) Long-term variability in secondary production of an intertidal bivalve population is primarily a matter of recruitment. J Anim Ecol 70:159-169

Videla JA, Chaparro OR, Thompson RJ, Concha II (1998) Role of biochemical energy reserves in the metamorphosis and early juvenile development of the oyster Ostrea chilensis. Mar Biol 132:635-640

Walker RL, Hurley DH, Kupfer R (1998) Growth and survival of Atlantic surfclam, Spisula solidissima, larvae and juveniles fed various microalgae diets. J Shellfish Res 17:211-214

Wilbur HM, Collins JP (1973) Ecological aspects of amphibian metamorphosis. Science 182:1305-1314

Young EF, Bigg GR, Grant A, Walker P, Brown J (1998) A modelling study of environmental influences on bivalve settlement in The Wash, England. Mar Ecol Prog Ser 172: $197-214$

Submitted: July 26, 2004; Accepted: April 18, 2006

Proofs received from author(s): December 18, 2006 